STUDIA I PRACE WYDZIAŁU NAUK EKONOMICZNYCH I ZARZĄDZANIA NR 42, T. 2

DOI: $10.18276 / \operatorname{sip} .2015 .42 / 2-01$

\author{
Arnold Bernaciak ${ }^{*}$ \\ Wyższa Szkoła Bankowa w Poznaniu
}

\title{
INWENTARYZACJA I WYCENA WARTOŚCI DRZEW W PRZESTRZENI PUBLICZNEJ KÓRNIKA W KONTEKŚCIE POSTULATÓW POLITYKI EKOLOGICZNEJ UNII EUROPEJSKIEJ
}

\section{STRESZCZENIE}

Polityka ekologiczna UE sformułowana w Strategii ochrony różnorodności biologicznej oraz Siódmym programie działań środowiskach wskazuje na konieczność identyfikacji i wyceny ekosystemów oraz ich świadczeń. Brak obowiązków prawnych w tym zakresie powoduje woluntarystyczny charakter potencjalnych działań w tej dziedzinie. Jednostkami, które mogą podjąć wyzwania stawiane przez politykę, są samorządy lokalne. Prezentowany przykład działań podjętych przez gminę Kórnik ukazuje możliwości realizacji postulatów polityki ekologicznej przez władze samorządowe kierujące się potrzebą wiedzy o lokalnym środowisku przyrodniczym i podnoszeniem jakości życia mieszkańców.

Słowa kluczowe: bioróżnorodność, drzewa, świadczenia ekosystemów, inwentaryzacja, wycena

\section{Wprowadzenie}

Polityka ekologiczna UE formułuje postulaty odnoszące się do poznania, inwentaryzacji, wyceny i ochrony świadczeń ekosystemów. Zapisy w tym zakresie zawarte są w Unijnej strategii ochrony różnorodności biologicznej oraz w Siódmym programie działań w zakresie ochrony środowiska.

\footnotetext{
*Adres e-mail: arnold.bernaciak@wsb.poznan.pl.
} 
$\mathrm{Na}$ terenach zurbanizowanych, o niewielkim udziale naturalnych ekosystemów szczególna rola w kształtowaniu środowiska życia człowieka przynależy drzewom. Dostarczają one szeregu świadczeń zasobowych, regulacyjnych i kulturowych. Jednocześnie świadomość władz, administracji i mieszkańców dotycząca występujących na danym terenie drzew, ich znaczenia i wartości ekonomicznej ma często ograniczony zakres. Drzewa traktowane są jako jeden z oczywistych elementów krajobrazu miejskiego. Nie przywiązuje się większej wagi do roli, jaką odgrywają w kształtowaniu jakości życia w mieście.

Celem niniejszego artykułu jest prezentacja inwentaryzacji, waloryzacji i wyceny drzew rosnących w przestrzeni publicznej miasta jako dobrej praktyki realizującej postulaty polityki ekologicznej UE. Innowacyjne, fakultatywne, niewynikające z obowiązków prawnych działanie podjęte przez gminę Kórnik prowadzi do poszerzenia zasobu wiedzy o drzewach rosnących na terenie miast. Sporządzona baza danych jest skutecznym instrumentem zarządzania wykorzystywanym przez administrację ochrony środowiska, a jednocześnie źródłem wiedzy i edukacji dla mieszkańców miasta.

\section{Zasoby przyrodnicze w Unijnej strategii ochrony różnorodności biologicznej oraz Siódmym programie działań środowiskowych UE}

Najważniejsze wyzwania UE w zakresie różnorodności biologicznej oraz świadczeń dostarczanych przez ekosystemy - ich identyfikacji i wyceny - zostały zdefiniowane w dwóch dokumentach o charakterze strategicznym. Pierwszy z nich to Unijna strategia ochrony różnorodności biologicznej do 2020 r. Drugi to Siódmy program działań w zakresie ochrony środowiska do roku 2020 - „Dobra jakość życia z uwzględnieniem ograniczeń naszej planety".

Przyjęta w roku 2011 Strategia bioróżnorodności UE definiuje najważniejsze w wymiarze strategicznym elementy odnoszące się do kwestii różnorodności przyrodniczej: wizję, cele i zadania ${ }^{1}$. Przewodni cel strategii określony został w perspektywie roku 2020. Jako nadrzędny kierunek wszystkich podejmowanych działań autorzy strategii wskazują powstrzymanie utraty różnorodności biologicznej i de-

\footnotetext{
${ }^{1}$ Komunikat Komisji do Parlamentu Europejskiego, Rady, Europejskiego Komitetu Ekonomiczno-Społecznego i Komitetu Regionów, Nasze ubezpieczenie na życie i nasz kapitat naturalny - unijna strategia ochrony różnorodności biologicznej na okres do 2020 r. (*COM/2011/0244).
} 
gradacji świadczeń ekosystemów oraz przywrócenie ich w możliwie największym zakresie. Uzasadnienie postawienia takiego celu zawarte zostało w Komunikacie Komisji ${ }^{2}$. Zwrócono w nim uwagę na niebagatelne znaczenie społeczne i gospodarcze bioróżnorodności oraz świadczeń dostarczanych przez ekosystemy.

Strategia bioróżnorodności odnosi się bezpośrednio do terenów o szczególnych wartościach przyrodniczych objętych ochroną w ramach sieci Natura 2000. Swoimi postulatami obejmuje także tereny rolnicze i leśne. Brak jest jednoznacznego odniesienia do terenów zurbanizowanych, jednak w strategii zawarto zapisy, które mają charakter uniwersalny i mogą zostać odniesione do obszarów miejskich. Taki charakter ma działanie piąte - Poprawa wiedzy na temat ekosystemów i ich usług w UE. Zapisano w nim, że państwa członkowskie zidentyfikują stan ekosystemów oraz ocenią wartość gospodarczą dostarczanych przez nie świadczeń. Ponadto, podjęte zostaną działania wspierające włączenie wartości świadczeń do systemów rachunkowości i sprawozdawczości.

Podobne zapisy zawarte zostały w Siódmym programie działań w zakresie ochrony środowiska ${ }^{3}$. W części przyjętych celów priorytetowych odnaleźć można wyzwania istotne dla zarządzania zasobami przyrodniczymi w miastach. W celu piątym zwrócono uwagę na istotną rolę badań naukowych oraz monitorowania środowiska. Pozyskana z tych źródeł wiedza powinna być dostępna dla zainteresowanych mieszkańców oraz decydentów, aby umożliwić jej praktyczne wykorzystanie. Z kolei cel siódmy zawiera zapisy dotyczące promowania i wspierania przez program inicjatyw związanych z innowacyjnością i wymianą najlepszych praktyk. Ponadto, w programie podkreślono znaczenie administracji lokalnej, wskazując na jej rolę w zachowaniu i wspieraniu kapitału naturalnego ${ }^{4}$.

W świetle powyższych zapisów można przyjąć, iż aktualna polityka ekologiczna UE wysyła w stronę władz publicznych postulaty:

a) identyfikacji stanu ekosystemów i dostarczanych przez nie świadczeń;

b) wyceny świadczeń ekosystemów;

c) poszerzania wiedzy o środowisku poprzez badania naukowe i monitoring środowiska;

\footnotetext{
${ }^{2}$ Tamże, s. 4.
}

${ }^{3}$ Decyzja Parlamentu Europejskiego i Rady nr 1386/2013/UE z 20 listopada 2013 r. w sprawie ogólnego unijnego programu działań w zakresie środowiska do 2020 r. „Dobra jakość życia z uwzględnieniem ograniczeń naszej planety”(L 354/171).

${ }^{4}$ Tamże, p. 86. 
d) upowszedniania i praktycznego wykorzystania wiedzy o ekosystemach i ich świadczeniach;

e) wprowadzania innowacyjnych rozwiązań;

f) wymiany informacji o najlepszych praktykach.

Jako że omawiane dokumenty podkreślają rolę, jaką w zarządzaniu zasobami przyrody odgrywają władze lokalne, można przyjąć, że powyższe postulaty adresowane są również w ich stronę.

\section{Rola i wartość drzew w przestrzeni miejskiej}

Rola drzew w przestrzeni miejskiej została szeroko omówiona i udokumentowana $\mathrm{w}$ dorobku nauki. Wielu autorów w swoich badaniach koncentruje się na funkcjach pełnionych przez drzewa. Identyfikują funkcje przestrzenne, przyrodnicze, społeczne i gospodarcze 5 . Szereg opracowań, opierając się na koncepcji usług ekosystemowych, wskazuje na świadczenia dostarczane przez drzewa ${ }^{6}$. Liczni autorzy podejmują próbę ich wyceny. Wśród najbardziej znanych należy wymienić badania Davida J. Nowaka, Daniela E. Crana i Johna F. Dwyera, którzy stosując metodę kompensacyjną, określili wartość drzew w kilku miastach Stanów Zjednoczonych ${ }^{7}$. Przykładowo: wartość ekonomiczna drzew rosnących w Bostonie została określona na 1,3 mld dolarów (wartość pojedynczego drzewa - 1058 dolarów). Z kolei Geoffrey H. Donovan i David T. Butry, stosując metodę cen hedonicznych do badania wartości drzew przyulicznych w Portland, ustalili ich sumaryczną wartość na 1,35 mld dolarów ${ }^{8}$. Świadczenia dostarczane przez

${ }^{5}$ Zob. np.: A. Łukasiewicz, S. Łukasiewicz, Rola i ksztaltowanie zieleni miejskiej, Wydawnictwo Naukowe Uniwersytetu im. Adama Mickiewicza w Poznaniu, Poznań 2011; H.B. Szczepanowska, Ekologiczne, społeczne i ekonomiczne korzyści z drzew na terenach zurbanizowanych, „Człowiek i Środowisko" 2007, nr 31.

${ }^{6}$ Zob. np.: B. Fisher, R.K. Turner, P. Morling, Defining and classifying ecosystem services, „Ecological Economics” 2009, nr. 63, s. 643-653; S. Farber, R. Costanza, M.A. Wilson, Economic and ecological concepts for valuinge cosystem services, „Journal of Ecological Economics” 2002, $\mathrm{nr}$ 41, 375-392; M. Giergiczny, J. Kronenberg, Jak wycenić wartość przyrody w mieście? Wycena drzew przyulicznych w centrum Łodzi, w: Zrównoważony rozwój - zastosowania 3, red. T. Bergier, J. Kronenberg, Fundacja Sendzimira, Kraków.

${ }^{7}$ D.J. Nowak, D.E. Crane, J.F. Dwyer, Compensatory Value of Urbantrees in the United States, „Journal of Arboriculture” 2002, nr 28, s. 194-199.

${ }^{8}$ G.H. Donovan, D.T. Butry, Trees in the City: Valuing Street Trees in Portland, Oregon, „Landscape and Urban Planning" 2010, no. 94, s. 77-83. 
drzewa zostały wykorzystane do wyceny ich wartości ekonomicznej w metodzie zastosowanej przez Paulę J. Peper i wsp. ${ }^{9}$. W badaniu przeprowadzonym w Nowym Jorku uwzględniono takie usługi, jak: pochłanianie zanieczyszczeń, retencja wody oraz wpływ na wartość nieruchomości. Analiza wykazała, że drzewa przyuliczne Nowego Jorku przynoszą jego mieszkańcom korzyści netto w wysokości 122 mln dolarów rocznie.

\section{Metodyka inwentaryzacji i wyceny wartości drzew na terenie Kórnika}

Badania przeprowadzone zostały w Kórniku. Liczące 7,5 tys. mieszkańców miasto rozciąga się na powierzchni $6 \mathrm{~km}^{2}$ i zlokalizowane jest kilkanaście kilometrów na południe od Poznania. Stanowi siedzibę władz gminy miejsko-wiejskiej.

Badania obejmowały inwentaryzację drzew rosnących w przestrzeni publicznej miasta oraz ich wycenę ${ }^{10}$. Inwentaryzację przeprowadzono w latach 2013-2014. Dla każdego z drzew określono gatunek, obwód, wysokość oraz współczynniki: urbanizacyjny, lokalizacyjny i kondycji. Lokalizacja każdego drzewa naniesiona została na mapę.

Na podstawie inwentaryzacji dokonano wyceny wartości ekonomicznej drzew. Została ona przeprowadzona dwiema metodami - kosztu odtworzenia oraz analizy korzyści. Wycena drzew metodą odtworzeniową została przeprowadzona zgodnie z zasadami opracowanymi przez Instytut Gospodarki Przestrzennej i Mieszkaniowej ${ }^{11}$. Metoda odwołuje się do kosztów odtworzenia drzewa, wyrażając wysokość rekompensaty finansowej za jego potencjalną utratę. Dla każdego drzewa określono jego wartość podstawową, którą urealniono poprzez zastosowanie kolejnych współczynników zgodnie z poniższymi wzorami:

- dla drzew o obwodzie 20/25 cm: $R W D=W P \times K \times L$

9 P.J. Peper, E.G. McPherson, J.R. Simson, S.L. Gardner, K.E. Vargas, Q. Xiao, New York - Municipal Forest Resource Analysis, University of California, Center for Urban Forest, Davis 2007.

${ }^{10}$ Inwentaryzacja i wycena drzew przeprowadzone zostały w ramach pracy magisterskiej: A. Paluch, Wycena wartości drzew na przykładzie miasta Kórnika, Wydział Biologii Uniwersytetu im. Adama Mickiewicza w Poznaniu, promotor: dr hab. Arnold Bernaciak, recenzent: dr hab. Julian Chmiel, Poznań 2014.

${ }^{11}$ Metoda wyceny wartości drzew na terenach zurbanizowanych dla warunków polskich, red. H.B. Szczepanowska, Instytut Gospodarki Przestrzennej i Mieszkalnictwa, Warszawa 2009. 
- dla drzew o obwodzie poniżej $20 \mathrm{~cm}: R W D=W P \times M \times K \times L$

- dla drzew o obwodzie powyżej $25 \mathrm{~cm}: R W D=W P \times G \times P \times K \times L$ gdzie:

$W P$ - wartość podstawowa w zł dla danego gatunku drzewa,

$K$ - współczynnik kondycji,

$L \quad$ - współczynnik lokalizacji,

$M$ - współczynnik zmniejszania wartości w zależności od wielkości obwodu pnia,

$G$ - współczynnik wartości gatunkowej,

$P \quad$ - współczynnik przyrostu drzewa.

Obok metody odtworzeniowej przeprowadzono również analizę korzyści opierającą się na wycenie świadczeń dostarczanych przez drzewa. Wyceną objęto tylko te świadczenia, których wartość można w stosunkowo dokładny sposób wyliczyć. Należą do nich: pochłanianie dwutlenku węgla, produkcja tlenu oraz retencja wody.

Z danych literaturowych zaczerpnięto informacje dotyczące ilości pochłanianego przez drzewa dwutlenku węgla, wytwarzanego tlenu oraz retencji wody ${ }^{12}$.

Dla określenia wartości jednostki pochłoniętego dwutlenku węgla przyjęto cenę europejskiego certyfikatu redukcji emisji dla rynku polskiego. Po dokonaniu odpowiednich przeliczeń walutowych oraz jednostkowych cenę1 $\mathrm{kg} \mathrm{CO}_{2}$ ustalono na $0,02 \mathrm{zł} / \mathrm{kg}$. Wartość jednostki produkowanego tlenu określono na podstawie oferty rynkowej tlenu medycznego. Najniższa cena $1 \mathrm{~kg}$ tlenu w okresie badawczym wynosiła 14 zł $/ \mathrm{kg}$. W przypadku retencji wartość została wyznaczona na podstawie kosztu funkcjonowania pompy wodnej. Biorąc pod uwagę pompę, która zapewnia najniższy koszt przepompowania jednostki wody, jej maksymalny pobór mocy oraz najniższą cenę energii, wartość przepompowania $1 \mathrm{~m}^{3}$ wody wyniosła $0,02 \mathrm{zz} / \mathrm{m}^{3}$.

Wartość wszystkich dostarczanych świadczeń została zsumowana i obliczona dla okresu 30 lat - wskazywanego przez administrację zieleni w mieście jako średni w badanej przestrzeni czas żywotności drzewa.

${ }^{12}$ Zob. np. D.J. Nowak, D.E. Crane, J.F. Dwyer, Compensatory Value of Urban Trees in the United States, ,Journal of Arboriculture” 2002, no. 28, s. 194-199; http://www.americanforests.org/discoverforests/tree-facts (24.05.2014); E.G. McPherson, Benefits of Trees, Watershed, Energy and Air, „Arborist News" 2004, no. 13, s. 29-35; http://www.mortonarb.org/trees-plants/benefits-trees/helping-ourenvironment (12.06.2014). 


\section{Drzewa na terenie Kórnika i możliwości wykorzystania badań}

W okresie badawczym w przestrzeni publicznej Kórnika rosło 2691 drzew. Zidentyfikowano 56 gatunków, w tym 42 gatunki drzew liściastych i 14 gatunków iglastych. Większość drzew posiada dobrą kondycję. Do tej kategorii zaliczono 69\% obiektów. W bardzo dobrej kondycji jest 16\%. Zła kondycja charakteryzuje jedynie 26 drzew, co stanowi 1\% całej badanej populacji.

Rzeczywista wartość wszystkich drzew w przestrzeni publicznej miasta obliczona metodą odtworzeniową wyniosła 56099 117,71 zł (średnia wartość jednego drzewa to 20 846,95 zł). Pomiar wartości metodą analizy korzyści daje bardzo podobne wyniki. Sumaryczna wartość wszystkich świadczeń w trzydziestoletnim okresie wynosi 55923 304,86 zł (pojedyncze drzewo - 20 781,61 zł). Warto podkreślić bardzo podobną wartość otrzymaną dwiema całkowicie różnymi metodami obliczeniowymi. Różnica dla pojedynczego drzewa wynosi 65,34 zł, co stanowi zaledwie $0,3 \%$ wartości uzyskanej metodą odtworzeniową.

Dla każdego drzewa przygotowana została metryczka opisująca jego podstawowe parametry. Znalazły się w niej wszystkie dane zbierane w trakcie inwentaryzacji i waloryzacji (rysunek 1). Ze zgromadzonych danych stworzono bazę danych obejmującą wszystkie zinwentaryzowane obiekty.

Rysunek 1. Metryczka informacyjna drzewa

\begin{tabular}{|c|c|c|}
\hline Nr obiektu & 874 & \\
\hline Ulica & plac Niepodległości & \\
\hline Gatunek & Robinia biała (akacjowa) & \\
\hline Nazwa łacińska & Robinia pseudoacacja & \\
\hline Obwód (cm) & 130 & \\
\hline Wysokość & 768 & \\
\hline Ogólna kondycja & Dobra & \\
\hline Rzeczywista wartość (zł) & 27151,00 & \\
\hline Wartość korzyści (zł, 30 lat) & 28815,60 & $=x^{4}$ \\
\hline Data badania & 14 sierpnia $2013 \mathrm{r}$. & $\boldsymbol{A}$ \\
\hline Autor & Aneta Paluch & 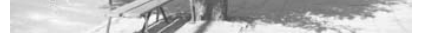 \\
\hline
\end{tabular}

Źródło: A. Paluch, Wycena wartości drzew na przykładzie miasta Kórnika, praca magisterska, UAM, 2014. 
Baza stanowi narzędzie wykorzystywane przez administrację w zarządzaniu zielenią na terenie miasta. Jest źródłem informacji wykorzystywanym przy tworzeniu miejscowych planów zagospodarowania przestrzennego, wydawaniu decyzji administracyjnych oraz sporządzaniu i analizie ocen oddziaływania na środowisko. Informacje o wartości drzew pozwalają precyzyjnie wskazać potencjalne koszty środowiskowe podejmowanych przedsięwzięć ingerujących w środowisko. Wspierają decyzje o kompensacji przyrodniczej.

\section{Podsumowanie}

Inwentaryzacja walorów i zasobów przyrodniczych stanowi kierunek działań wskazywanych w strategicznych dokumentach UE: Siódmym programie działań środowiskowych oraz Strategii ochrony różnorodności biologicznej. Inwentaryzacja i wycena drzew przeprowadzone na terenie Kórnika realizują postulaty stawiane w tych dokumentach (tabela 1).

Tabela 1. Realizacja postulatów polityki ekologicznej UE

\begin{tabular}{|c|l|l|}
\hline Lp. & \multicolumn{1}{|c|}{ Postulat } & \multicolumn{1}{|c|}{ Realizacja } \\
\hline 1. & $\begin{array}{l}\text { Identyfikacja stanu ekosystemów } \\
\text { i dostarczanych przez nie świadczeń }\end{array}$ & $\begin{array}{l}\text { Identyfikacja stanu wszystkich drzew w przestrzeni } \\
\text { publicznej miasta oraz identyfikacja dostarczanych } \\
\text { świadczeń }\end{array}$ \\
\hline 2. & Wycena świadczeń ekosystemów & $\begin{array}{l}\text { Wyceny zinwentaryzowanych drzew (metoda odtwo- } \\
\text { rzeniowa) oraz dostarczanych przez nie świadczeń } \\
\text { (analiza korzyści) }\end{array}$ \\
\hline 3. & $\begin{array}{l}\text { Poszerzenie wiedzy o środowisku } \\
\text { poprzez badania naukowe i monito- } \\
\text { ring środowiska }\end{array}$ & $\begin{array}{l}\text { Baza danych - zasób wykorzystywany przez admini- } \\
\text { strację. Wydanie książkowe inwentaryzacji - poszerza- } \\
\text { nie wiedzy mieszkańców o walorach przyrodniczych } \\
\text { miasta }\end{array}$ \\
\hline 4. & $\begin{array}{l}\text { Upowszednianie i praktyczne wyko- } \\
\text { rzystanie wiedzy o ekosystemach } \\
\text { i ich świadczeniach }\end{array}$ & $\begin{array}{l}\text { Wykorzystanie bazy danych w zarządzaniu zielenią na } \\
\text { terenie miasta }\end{array}$ \\
\hline 5. & $\begin{array}{l}\text { Wprowadzenia innowacyjnych } \\
\text { rozwiązań }\end{array}$ & $\begin{array}{l}\text { Jedna z pierwszych w Polsce inwentaryzacji i wycen } \\
\text { drzew przeprowadzonych w skali całego miasta }\end{array}$ \\
\hline 6. & $\begin{array}{l}\text { Wymiana informacji o najlepszych } \\
\text { praktykach }\end{array}$ & $\begin{array}{l}\text { Wyniki inwentaryzacji i waloryzacji opublikowane } \\
\text { w postaci książkowej i dostępne w internecie }\end{array}$ \\
\hline
\end{tabular}


Dzięki inwentaryzacji i rozpoznaniu kondycji poszczególnych drzew zrealizowano postulat identyfikacji stanu ekosystemów. Z kolei wycena wartości świadczeń była bezpośrednią realizacją postulatu wskazującego potrzebę dokonywania takich wycen. Przeprowadzone badanie i analizy w znaczny sposób podniosły wiedzę o zasobach środowiskowych miasta. Wiedza ta jest na co dzień wykorzystywana w działaniach administracyjnych i strategicznych urzędu miasta. Jednocześnie dzięki jej książkowemu upowszechnieniu staje się dostępna dla wszystkich zainteresowanych, w tym w szczególności dla mieszkańców Kórnika. Postulatem wskazywanym przez dokumenty strategiczne UE jest innowacyjność stosowanych rozwiązań. Wycena wartości środowiska przyrodniczego jest zagadnieniem dyskutowanym na forum naukowym. Brak jednak formalnych wytycznych, a w szczególności przepisów prawnych w tym zakresie, powoduje trudności w praktycznym stosowaniu rozwiązań omawianych na gruncie teoretycznym. W świetle tego unikatowej w skali kraju próbie wyceny wartości wszystkich drzew w przestrzeni publicznej miasta przypisać można atrybut innowacyjności.

\section{Literatura}

Decyzja Parlamentu Europejskiego i Rady nr 1386/2013/UE z 20 listopada 2013 r. w sprawie ogólnego unijnego programu działań w zakresie środowiska do 2020 r. „Dobra jakość życia z uwzględnieniem ograniczeń naszej planety” (L 354/171).

Donovan G.H., Butry D.T., Trees in the City: Valuing Street Trees in Portland, Oregon, „Landscape and Urban Planning” 2010, no. 94.

Farber S., Costanza R., Wilson M.A., Economic and Ecological Concepts for Valuing Ecosystem Services, „Journal of Ecological Economics” 2002, no. 41.

Fisher B., Turner R.K., Morling P., Defining and Classifying Ecosystem Services, „Ecological Economics" 2009, no. 63.

Giergiczny M., Kronenberg J., Jak wycenić wartość przyrody w mieście? Wycena drzew przyulicznych w centrum Łodzi, w: Zrównoważony rozwój - zastosowania, t. III, red. T. Bergier, J. Kronenberg, Fundacja Sendzimira, Kraków 2012.

http://www.americanforests.org/discover-forests/tree-facts.

http://www.mortonarb.org/trees-plants/benefits-trees/helping-our-environment.

Komunikat Komisji do Parlamentu Europejskiego, Rady, Europejskiego Komitetu Ekonomiczno-Społecznego i Komitetu Regionów, Nasze ubezpieczenie na życie i nasz kapitał naturalny - unijna strategia ochrony różnorodności biologicznej na okres do 2020 r. (*COM/2011/0244). 
Łukasiewicz A., Łukasiewicz S., Rola i kształtowanie zieleni miejskiej, Wydawnictwo Naukowe Uniwersytetu im. Adama Mickiewicza, Poznań 2011.

McPherson E.G., Benefits of Trees, Watershed, Energy and Air, „Arborist News” 2004, no. 13. Metoda wyceny wartości drzew na terenach zurbanizowanych dla warunków polskich, red. H.B. Szczepanowska, Instytut Gospodarki Przestrzennej i Mieszkalnictwa, Warszawa 2009.

Nowak D.J., Crane D.E., Dwyer J.F., Compensatory Value of Urban Trees in the United States, ,Journal of Arboriculture” 2002, no. 28.

Peper P.J., McPherson E.G., Simson J.R., Gardner S.L., Vargas K.E., Xiao Q., New York Municipal Forest Resource Analysis, University of California, Center for Urban Forest, Davis 2007.

Szczepanowska H.B., Ekologiczne, społeczne i ekonomiczne korzyści z drzew na terenach zurbanizowanych, „Człowiek i Środowisko” 2007, nr 31.

\title{
IMPLEMENTATION OF THE DEMANDS OF ENVIRONMENTAL POLICY OF THE EUROPEAN UNION: LOCAL INVENTORY AND VALUATION OF TREES IN PUBLIC SPACES OF KÓRNIK
}

\begin{abstract}
Environmental policy of the European Union, formulated in The $7^{\text {th }}$ Environment Action Programme and in The EU Biodiversity Strategy indicates the need for the identification and valuation of ecosystems and their services. The lack of legal requirements determined the optional nature of all actions taken in this field. One of the units that can take the environmental policy challenges are local governments. The article presents an example of the inventory and the valuation of trees taken by the municipality of Kórnik, Poland. It shows the feasibility of implementation of demands of the UE environmental policy by local authorities, guided by the need for knowledge of the local nature and raising the quality of life.
\end{abstract}

Keywords: biodiversity, trees, ecosystem services, inventory, valuation

JEL Code: Q57

Translated by Arnold Bernaciak 